\title{
CUSTOMER-BASED BRAND EQUITY OF A TOURISM DESTINATION: AN EMPIRICAL STUDY OF THE LIBEREC REGION
}

\section{${ }^{a}$ LENKA ČERVOVÁ, ${ }^{b}$ KAROLINA PAVLŮ}

\author{
Technical University of Liberec, Voroněžská 13, Liberec 1, \\ 46001, Czech Republic
}

email: ${ }^{a}$ lenka.cervova@tul.cz, ${ }^{b}$ karolina.pavlu@tul.cz

This paper was processed under the SGS grant - Brand equity as instrument of destination marketing management. \begin{abstract}
The aim of this contribution is to explore the demand-side of the tourism destination and to investigate whether the destination brand could be evaluated by the model of cut presented study is focused on the Liberec Region as a destination. The data was gathered by the means of the structured questionnaire and exploratory factor analyses were run to test and reduce the items within the sub-dimensions of CBBETD. It was found that CBBETD for the Liberec Region consists of four sub-dimensions awareness, image that includes four factors (outdoor, technical attractions, entertainment and non-traditional recreation), perceived quality including two factors (cleanliness and services) and loyalty
\end{abstract}

Keywords: branding, tourism, destination, brand-equity, marketing, customer

\section{Introduction}

According to 2016 UNWTO report, there has been 4\% increase in the number of global tourist arrivals during the last decade with a record of 1.2 billion tourist arrivals in 2015. This has increased inter-destination competition and has prompted destination planners to differentiate their destinations with strong unique selling propositions. It is very important for destination planners to implement useful strategies for branding destinations in order to behave differently as a viable choice of destination when addressing potential and loyal tourists.

The main purpose of this paper is to present the concept from tourists' point of view. The question is whether a customerbased brand equity methodology, traditionally developed for product brands and partly for services and organizations, can be transferred to destinations. Another question is application of the proposed dimensions regardless of a destination. Thus, it is relevant to ask whether a destination's image, as the single measure brand equity, represents the most vital element in the destination evaluation. Most of the previous studies have focused on the brand equity of a tourist destination at the national level rather than a regional one. The presented empirical study was conducted in the Liberec Region that lies in the north of the Czech Republic. Although the region consists of four tourist regions - Ceskolipsko, Jizera Mountains, Krkonose Mountains and Bohemian Paradise, the destination marketing is managed by the tourism department of the Regional Authority of the Liberec Region.

\section{Literature Review}

\subsection{Branding}

Modern branding is often traced back to the early nineteenth century (Room, 1992). Accepting Kotler's (1991) definition of a brand, “... a name, term, sign, symbol or design...intended to identify the goods or services of one seller or group of sellers and to differentiate them from those of competitors", branding as a concept is applied not only to commodities and companies but also to fields of tourism. Branding of the destination is one of the main topics in tourism marketing in terms of enhancing differentiation and competitiveness, but establishing a strong brand has increasingly been of significant concern because of fierce competition between places for visitor expenditures.

A brand receives its value from customers by providing a clue to product stability, performance and other traits in reaction to a company marketing strategy. That means you know what to expect in the way of performance. Keller (1993) termed this response "customer-based brand equity". Destination brands differ from product brands.
Destination branding is a relatively new field of study in tourism. For that reason destination branding faces the problem of using the same and already accepted branding principles and their transfer to destinations. Destination brands significantly differ from product brands in a numerous ways. Destinations provide other quality than material or financial that can be refunded. Destinations are places of life and change. Change is measure of brand stability, one of the main elements of branded consumer products. Destinations are multidimensional and provide different experiences to different tourists (Konecnik, 2010).

Therefore destination brands burden themselves with high risk of change of the brands' constitution. Potential modification may easily occur, sometimes intentionally and sometimes by natural or human influences. Other key differences are that destinations are not sold in the marketplace and they are unique.

\subsection{Brand Equity in Tourism}

Brand equity is a fundamental, basic concept in brand management (Aaker, 1996; Keller, 1993, 2003). From a marketing perspective, according to Aaker $(1991,1996)$ and Keller (1993), brand equity is described as "the value of the brand in the consumers" minds and, in particular, is defined as the differential effect exerted by brand awareness on the response of the consumer towards the brand (Keller, 1993, 2016), or as the perceived utility and overall superiority of a product because of its brand name, in comparison with other brands. Since its appearance in the 1990s (Aaker, 1991; Keller, 1993), the concept of brand equity has become a significant topic in tourism marketing literature. Brand equity is a straightforward concept as it refers to the value of a product attached to a specific name. Equity is derived from what the sale of the branded product would bring in the marketplace over and above the sale of an essentially similar product but without the added value of the brand name (Simon and Sullivan, 1990 from Keller, 1993). In the past, branding research was mostly associated with tangible goods (Marshall and Keller, 1999). Lately research focused on analyzing services brands (de Chernatony and McDonald, 2001) and corporate brands (Dowling, 2002). Finally, destination branding arose as the newest research area (Cai, 2002; Konecnik, 2004; Tasci, Gartner and Cavusgil, 2007). Experts have naturally discussed the extent to which the product branding principles could be used to service and corporate brands.

The first studies on brand equity in tourism were applied to hotels (Cobb-Walgren et al., 1995), restaurants (Kim and Kim, 2007) and airlines (Chen and Tseng, 2010).

The world of tourism image studies was quickly transforming into a world of destination brand studies since the Cai (2002) study. The concept of brand equity has evoked a huge interest among marketing researchers during the last two decades (Aaker, 1991 and 1996; Keller, 1993 and 1998). In comparison with number of work on the tourism destination image concept, including a quality dimension too, the other dimensions of brand equity have been less intensively studied. Destination brand equity was introduced in the work of Konecnik and Gartner (2007). In this study, destination brand is analysed from the consumer perspective as a multidimensional concept consisting of brand awareness, image, quality, perceived value and loyalty.

While applying the concept of brand theory to destinations, (Gartner \& Ruzzier, 2011) it is essential to take into account that destination branding is more complex and difficult apart from branding products. Proper management and marketing of destinations is inevitable because there is a very little and limited involvement of the destination marketers and various related agencies in the process (Same \& Vasquez, 2014). It is very 
important for destination managers to implement useful strategies for branding destinations in order to behave differently in adressing potential and loyal tourists and to become a more favourable choice of destination (Atadil, Turk \& Altintas, 2015). Pike and Bianchi (2016) also argued in favor of destination branding for creating destinations with high customer based brand equity (Mar, Carmen \& Arturo, 2015) leading to high destination awareness and positive tourist associations. For destinations, the concept of brand-equity stresses the importance of destination branding in developing marketing strategies for destinations to produce positive emotional values based on previous tourist's experience with the destination.

\subsection{Customer-based Brand Equity}

As a relatively newly developed concept, the idea of customerbased brand equity (CBBE) has attracted great interest in the last two decades. One of the most commonly accepted definitions of the CBBE concept was introduced by Keller (1998), who defined it 'as the differential effect that brand knowledge has on consumer response to the marketing of that brand'. Moreover, according to Keller, knowledge about brand is constructed by an associative network memory model in terms of two dimensions, brand awareness and brand image. Since that time, many interesting studies on CBBE have been issued. However, some authors pointed out the fact of insufficient theoretical background and variety of attitudes to this matter (Yoo and Donthu, 2001). Thus it is possible to say that the former interest in brand equity evolved later in a broader field of study in marketing (Barwise, 1993).

It is necessary to research customer-based brand equity of a tourism destination (CBBETD) from the perspective of tourists and their experience of the destination. CBBETD evaluates two wide aspects of a destination from visitors' point of view. The first assessed aspect is the measurement of tourists' perceptions of brand image, brand awareness, and brand associations. The second researches tourists' behavior which considers loyalty aspect for the destination (Baker \& Cameron, 2008). Keller (1998) was the one who framed the concept of customer-based brand equity and described it as "the differential effect that brand knowledge has on consumer response to the marketing of that brand".

Pike (2007) introduced the concept of CBBETD to measure the effectivness of a destination brand based on the brand values to the consumer. This way was filled the gap between past marketing efforts and conceptualizing CBBE for a destination as the hierarchy of brand characteristic, brand associations, brand resonance and brand loyalty.

Followingly work of Konecnik and Gartner (2007) listed awareness, image, quality and loyalty dimensions of destination as antecedents to CBBETD. They state that tourists from different backgrounds sense various dimensions of destination distinctly. The customer's evaluation of a brand includes awareness, image, quality and loyalty dimensions (see Figure 1).

Fig. 1: Customer-based brand equity for a tourism destination

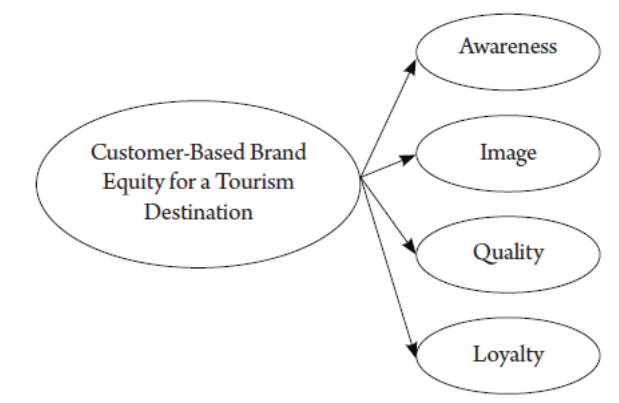

Source: own processing.

The four proposed dimensions with respect to destinations are elaborated below.
Destination Awareness

This term comes from behavioural studies of consumer and was thoroughly described in the tourism decision process by Goodall (1993). Although awareness is the first and necessary step in the decision process, and may lead to initial or repeated visit of destination, it is on the other hand insufficient, because the very awareness provides only a set of choice (Goodall, 1993). Awareness implies that an image of the destination exists in the minds of potential tourists (Gartner, 1993). If a destination desires becoming tourist preffered, it must first achieve tourist destination awareness and second a positive destination image.

\section{Destination Image}

However the research of the destination image dates back to 1970s (Gunn, 1972; Hunt, 1975) and Pike (2002) found almost 150 articles observing destination image topics over last three decades, still there is missing a common frame that would cover this area. While mostly studied in marketing, the term also crosses over other disciplines, such as anthropology, geography, sociology, and semiotics (Gallarza et al, 2002). According to Gartner (1993) these various studies lack the theoretical and conceptual framework for what constitutes a destination's image, its formation process (Gartner 1993), and its operationalization (Echtner and Ritchie, 1993). For the purpose of the presented survey the destination image is understood as "an interactive system of thoughts, opinions, feelings, visualizations, and intentions toward a destination” (Tasci et al, 2007). Although it is uneasy to support the term destination image with researchers' theories, it might be undoubtedly acknowledged that the destination image is important in tourists' evaluation and selection process.

\section{Destination Quality}

Destination quality is another key aspect of CBBETD, nevertheless quality measurement is a very complex process. In order to achieve results on quality it is necessary research tourists' evaluation of a destination products and services and tourists' experience (Prichard and Smith, 2000). All these elements are constituents that affect consumer behaviour and preference. According to Konecnik (2010) the aspect of destination quality is the most important component. When researching destination quality, a distinction between perceived quality and tourists' satisfaction should be taken into account (Prichard and Smith, 2000).

\section{Destination Loyalty}

The concept of destination loyalty is by Oppermann (2000) inevitable for destination brand research. The destination loyalty affects tourists in their future decisions and their choice of destination. However, Opperman (2000) states that destination loyalty should be examined in a long-term range and then it can serve as a usefull tool for prediction of future destination choice.

The concept of CBBETD has been tested for many destinations by various researchers. For example, Boo, Busser, and Baloglu (2009), Ford and Purwanegara (2013) and Far (2014) measured the customer based brand equity for tourist destinations for Las Vegas and Atlantic, Indonesia, and Kish Islands respectively and all argued in favour of treating destinations as brands for unique differentiation (Pike \& Bianchi, 2016; Mar, Carmen \& Arturo, 2015).

\section{Research Methodology}

The purpose of the presented study was to further develop and test the CBBETD model in the context of the Liberec Region. The research methodology uses the concept for the CBBETD developed and further refined by Konecnik (2010). The concept includes four sub-dimensions - awareness, image, perceived quality and loyalty. Three attributes for the dimension awareness and three for the loyalty were borrowed as they present factors applicable regardless of destination. However, the CBBETD scale was developed and tested for other destinations. Therefore some modifications within the sub-dimension image and perceived quality were necessary to reflect the appropriate aspects of the Liberec Region. For this purpose three focus 
groups with total 30 potential respondents were realized. The aim of these focus groups was to generate the attributes specific for the Liberec Region that affects its image and perceived quality. Respondents were not presented any attributes so their opinions were not affected. Personal subjective perception, expectations and experience was determining. The result of the interviews was 32 attributes that were assigned to subdimensions image and perceived quality.

The data for the main research were collected by the means of the structured questionnaire in form of face-to-face interviews across various tourist locations in the Liberec Region. Apart from the attributes for CBBETD model the questionnaire included other characteristics regarding the travelling to and in the Liberec Region (such as frequency of visit, purpose of visit, length of stay and travel companions). Totally 38 attributes transformed in the statements about the Liberec Region were measured on the scale from 1 to 5 where 1 was strongly disagree and 5 strongly agree with the statement.

Tourists aged older than 18 years were invited to participate in the survey. Quota sampling based on the gender and age was used so that the sample complied with the profile of the visitor of the Liberec Region monitored by the tourism department of the Regional Authority. The data was processed in the IBM SPSS Statistics using the methods of the descriptive statistics. The factors determining the sub-dimensions were identified by the exploratory factor analysis using the principal components and the Varimax rotation method. The appropriateness of exploratory factor analyses was determined by examining the correlation matrix of CBBETD attributes. Barlett's test of sphericity showed that the correlation matrix has significant correlations (significant at 0.000 for all conducted analyses). Table 1 shows the Kaiser-Meyer-Olkin (KMO) value. Since the KMO values varied from 0.664 to 0.902 , all of the variables can be considered as valid. Cronbach's Alpha coefficients to reflect the reliabilites associated with each of the sub-dimension are shown in Table 1. The coefficients (from 0.763 to 0.909 ) mean acceptable to excellent results.

Tab. 1: Validity and reliability check

\begin{tabular}{|c|c|c|c|}
\hline & KMO & $\begin{array}{c}\text { Total Variance } \\
\text { Explained }\end{array}$ & $\begin{array}{c}\text { Cronbach's } \\
\text { Alpha }\end{array}$ \\
\hline Awareness & 0.708 & 72.14 & 0.805 \\
\hline Image & 0.902 & 57.08 & 0.909 \\
\hline Quality & 0.854 & 53.00 & 0.822 \\
\hline Loyalty & 0.664 & 67.96 & 0.763 \\
\hline
\end{tabular}

Source: own processing.

There were 263 completed questionnaires. Nevertheless the elimination of problematic questionnaires reduced the sample size to 251. Although the Liberec Region is visited also by foreign tourists (especially German and Polish), the survey focused only on the Czech tourists. In terms of gender of the visitors, $51 \%$ were male and $49 \%$ female. Out of total respondents, $31 \%$ tourists were in the age group 31-40 years, $28 \%$ were $18-30$ years, $23 \%$ of respondents were in the age group 41-50 years, $12 \%$ were 51-60 years and $6 \%$ were older than 61 years. Occupation analysis revealed that $49 \%$ were employees, $21 \%$ entrepreneurs, $17 \%$ students, $10 \%$ retired or on maternity leave and $3 \%$ unemployed. As per the monthly netto income of the household it was found that $38 \%$ earned in the range of $25001 \mathrm{CZK}-45000 \mathrm{CZK}, 34 \%$ lower than $25000 \mathrm{CZK}, 21 \%$ in the range of $45001 \mathrm{CZK}$ - $65000 \mathrm{CZK}$ and $7 \%$ earned more than $65000 \mathrm{CZK}$ in a month.

\section{Data Analyses and Discussion}

Factor analysis was run to test and reduce the various items within the four sub-dimensions of CBBETD. The first subdimension that was examined was awareness. Respondents' awareness of the Liberec Region as a tourism destination is actually quite high as can be seen in Table 2 (mean for given variables from 3.87 to 3.99). Three variables were found to load highly on a single factor ("awareness"). These three items are able to explain $72.14 \%$ of the variability and the reliability is reasonably high at 0,805 (see Cronbach’s Alpha in Table 1)

Tab. 2: Awareness

\begin{tabular}{|l|c|c|}
\hline \multicolumn{1}{|c|}{ Variables } & Mean & $\begin{array}{c}\text { Factor } \\
\text { Loading }\end{array}$ \\
\hline Attractive and known TD & 3.93 & 0.871 \\
\hline Popular destination & 3.87 & 0.842 \\
\hline Characteristics of TD & 3.99 & 0.834 \\
\hline \% Variance extracted & 72.14 \\
\hline
\end{tabular}

Source: own processing.

The second sub-dimension to examine was image. The factor analysis results can be found in Table 3 . In this case the factor analysis was run five times with consecutive eliminating variables that were not part of any factor. The aim of this procedure is to eliminate items with low factor loading (lower than 0.500 ) and to explain possible highest percentage of the variability. Fifth factor analysis suggested four factors that explain $57.08 \%$ of variability. The first one can be named as "outdoor" and includes mountains, nature, towns and villages, architecture, historical attractions and sport activities. The second factor named as "technical attractions" comprises variables such as technical sights, small breweries, museums and cultural attractions. Two items - friendly people and weather were also added to this factor. They are related to the aforementioned variables as visiting technical sights or museums might be connected with the weather (that was not seen very high by the respondents - mean 3.24) and often people personnel that creates the experience of tourists. The third factor identified as "entertainment" includes entertainment facilities, gastronomy facilities, local food and shopping facilities. The last factor named as "non-traditional recreation" includes nontraditional experiences, spa resorts and connection with famous personalities. Looking at the means for variables within the subdimension image, it is obvious that respondents evaluated very high nature (4.33), mountains (4.32) and sport attractions (4.04). On the other hand measures such as pleasant weather (3.24) or modern health resorts (3.13) were perceived to be poor. Similar results were supported by the qualitative study (focus groups) in which participants put value on diverse countryside in the Liberec Region, good conditions for practicing various sport and recreation activities. Furthermore the qualitative work did indicate bad weather making outdoor activities more difficult. On the contrary according to the respondents' opinion, the Liberec Region offers numerous activities and sights (especially technical) that can be visited in case of bad weather conditions.

The third sub-dimension that was examined was perceived quality. The factor analysis identified two factors that explain $53 \%$ of the variability (Table 4 ). The first factor "cleanliness" includes cleanliness, infrastructure, safety, accommodation facilities and unpolluted environment. The second factor "services" consists of quality of gastronomy facilities, ease of visit access, service quality and good value for money. The most positive reactions were for the ease of access to the region (3.93) that reflects the fact that the center of the region (Liberec) is accessible in one hour drive from Prague. Nevertheless the quality of infrastructure achieved lower value (3.43). These views of the quality of the region by the tourists create a need to look more deeply into these perceptions and consider upgrading transport infrastructure around the region in order to achieve a better overall impression for future and present visitors. 
Tab. 3: Image

\begin{tabular}{|c|c|c|c|c|c|}
\hline \multirow[b]{2}{*}{ Variables } & \multirow[b]{2}{*}{ Mean } & \multicolumn{4}{|c|}{ Factor loading } \\
\hline & & Outdoor & $\begin{array}{c}\text { Technical } \\
\text { attractions }\end{array}$ & Entertainment & $\begin{array}{l}\text { Non-traditional } \\
\text { recreation }\end{array}$ \\
\hline Beautiful mountains & 4.32 & 0.816 & 0.109 & -0.012 & 0.072 \\
\hline Beautiful nature & 4.33 & 0.791 & 0.196 & 0.017 & -0.018 \\
\hline Good opportunities for recreation activities & 3.97 & 0.716 & 0.133 & 0.267 & 0.049 \\
\hline Lovely towns and villages & 3.83 & 0.713 & 0.138 & 0.210 & 0.120 \\
\hline Interesting historical attractions & 3.87 & 0.712 & 0.229 & 0.213 & 0.077 \\
\hline Interesting architecture & 3.76 & 0.673 & 0.196 & 0.247 & 0.102 \\
\hline Good sport attractions & 4.04 & 0.533 & 0.426 & 0.180 & -0.015 \\
\hline Technical attractions & 3.55 & 0.129 & 0.684 & 0.113 & 0.225 \\
\hline Pleasant weather & 3.24 & 0.211 & 0.674 & -0.062 & 0.021 \\
\hline Small breweries & 3.60 & 0.071 & 0.606 & 0.189 & 0.349 \\
\hline Museums & 3.63 & 0.320 & 0.561 & 0.200 & 0.265 \\
\hline Interesting cultural attractions & 3.73 & 0.274 & 0.521 & 0.435 & 0.115 \\
\hline Friendly and hospitable people & 3.49 & 0.168 & 0.517 & 0.190 & -0.001 \\
\hline Good nightlife and entertainment & 3.61 & 0.282 & -0.001 & 0.758 & 0.072 \\
\hline Wide range of gastronomy facilities, local food & 3.76 & 0.120 & 0.405 & 0.649 & 0.060 \\
\hline Good shopping facilites & 3.94 & 0.218 & 0.227 & 0.583 & 0.218 \\
\hline Connection with famous personalities & 3.29 & -0.013 & 0.125 & 0.110 & 0.841 \\
\hline Modern health resorts & 3.13 & 0.189 & 0.217 & -0.069 & 0.702 \\
\hline Non-traditional experiences & 3.37 & 0.028 & 0.073 & 0.391 & 0.653 \\
\hline \% Variance Extracted & & 21.09 & 14.66 & 10.93 & 10.40 \\
\hline
\end{tabular}

Tab. 4: Perceived quality

\begin{tabular}{|l|c|c|c|}
\hline \multicolumn{1}{|c|}{ Variables } & \multirow{2}{*}{ Mean } & \multicolumn{2}{c|}{ Factor Loading } \\
\cline { 3 - 4 } & & Cleanliness & Services \\
\hline High level of cleanliness & 3.37 & 0.761 & 0.066 \\
\hline $\begin{array}{l}\text { High quality of } \\
\text { infrastructure }\end{array}$ & 3.43 & 0.731 & 0.085 \\
\hline $\begin{array}{l}\text { High level of personal } \\
\text { safety }\end{array}$ & 3.52 & 0.620 & 0.297 \\
\hline $\begin{array}{l}\text { High quality of } \\
\text { accommodation }\end{array}$ & 3.66 & 0.582 & 0.312 \\
\hline Unpolluted environment & 3.71 & 0.515 & 0.316 \\
\hline High quality of gastronomy & 3.56 & 0.094 & 0.819 \\
\hline Ease of visit access & 3.93 & 0.141 & 0.762 \\
\hline High quality of services & 3.69 & 0.428 & 0.649 \\
\hline Good value for money & 3.69 & 0.458 & 0.526 \\
\hline \% Variance extracted & & 28.05 & 24.95 \\
\hline \multicolumn{2}{|l|}{} \\
\hline
\end{tabular}

Source: own processing.

The final sub-dimension was loyalty. The factor analysis results can be seen in Table 5 . The conducted analysis showed high loadings on a single factor ("loyalty"). The reliability measured by Cronbach's Alpha (0.763) was acceptable (Table 1 ). Tourists visiting the Liberec Region would recommend it their friends and relatives (mean 4.12), speak of very high of the Liberec Region regarding services and facilities (mean 3.90) and intent to visit the Liberec Region again (4.29). These three variables were able to explain $67.96 \%$ of the total variance.

Tab. 5: Loyalty

\begin{tabular}{|l|c|c|}
\hline \multicolumn{1}{|c|}{ Variables } & Mean & $\begin{array}{c}\text { Factor } \\
\text { Loading }\end{array}$ \\
\hline Recommend TD to friends & 4.12 & 0.875 \\
\hline Speak highly of services and facilities in TD & 3.90 & 0.808 \\
\hline Visit TD in the future & 4.29 & 0.788 \\
\hline \% Variance extracted & & 67.96 \\
\hline
\end{tabular}

Source: own processing.

\section{Conclusion}

In conclusion, the model of customer-based brand equity for a tourism destination was found to be adaptable for the Liberec Region and with some modifications appropriate for use in this context. Nevertheless, the sub-dimension image needed to be highly modified to reflect the specifities of this tourist destination. The sub-dimension image includes outdoor, technical attractions, entertainment and non-traditional recreation. It was also found that there were two separate dimensional factors for the sub-dimension perceived quality cleanliness and services.

The use of this model is helpful since it provides strategic options for the Liberec Region to improve its positioning and competitiveness in the tourist market. Although the Liberec Region (especially Liberec) is known for its above-average rainfall, it was proved that there exist alternative tourism sights or activities for case of bad weather such as technical sights or museums.

What needs to be mention is that this model is based only on perspective of tourists. To get a comprehensive view of the brand equity of a tourist destination it is necessary to take also perceptions of other stakeholders (citizens, local business, employees etc.) into consideration. This should be the subject of future research.

\section{Literature:}

1. Aaker, D.A.: Building Strong Brands. The Free Press, New York,1996. ISBN: 002900151X.

2. Atadil, H.A., Sirakaya, T.E. and Altintas, V.: An analysis of destination image for emerging markets of Turkey. Journal of vacation marketing, 2015, Vol. 20, No.3, pp. 195-210. doi: 10.1177/1356766712449366.

3. Cai, L.: Cooperative Branding for Rural Destination. Annals of Tourism Research, 2002, Vol. 29, pp. 720-742.

4. Echtner, C. M., Ritchie, J. R. B.: The measurement of destination image: An empirical assessment. Journal of Travel Research, 1993, Vol. 31, No. 4, pp. 3-13. doi: 10.1177/004 728759303100402

5. Gallarza, M.G., Gil, S.I. and Calderon, G.H.: Destination image: Towards a conceptual framework. Annals of Tourism Research, 2002, Vol. 29, No. 1, pp. 56-78. ISBN: 0160-7383.

6. Gartner, W.C.: Image Formation Process. In Uysal, M. and Fesenmaier, D. R. (Ed.): Communication and Channel Systems in Tourism Marketing. New York: The Haworth Press, Vol. 994, pp. 191-215. doi: https://doi.org/10.1300/J073v02n02_12.

7. Goodall, B.: How tourists choose their holidays: An analytical framework, in Goodal, B. and Ashworth, G. (Ed.): Marketing in the Tourism Industry: The Promotion of Destination Regions. Routledge, London, 1993, pp.1-17.

8. Gunn, C. A.: Vactionscape: Designing Tourist Regions. Austin, TX: Bureau of Business Research, University of Texas, 1975. 
9. Hunt, J. D.: Image as a factor in tourism development. Journal of Travel Research, 1975, Vol. 13, No. 1, pp. 1-7. doi: https://doi.org/10.1177/004728757501300301.

10. Chernatony, L. and McDonald, M.: Creating Powerful Brands in Consumer, Service and Industrial Markets. Oxford: Butterworth-Heinemann, 2001. ISBN: 0-7506-5980-7.

11. Keller, K. L.: Conceptualizing, Measuring, and Managing Customer-Based Brand Equity. Journal of Marketing, 1993, Vol. 57, No.1, pp. 1-22. doi: http://dx.doi.org/10.2307/1252054.

12. Kim, T.H., Kim, J.S.: Research on the effectiveness of communication activities in brand equity,focused on family restaurant. Hotel Manag. Res., 2007, Vol. 16, pp. 155-168.

13. Konecnik, M.: Evaluating Slovenia's image as a tourism destination: A self-analysis process towards building a destination brand. Journal of Brand Management, 2004, Vol. 11, No. 4, pp. 307-316.

14. Konecnik, M. and Gartner, W.C.: Customer-based brand equity for a destination. Annals of Tourism Research, 2007, Vol. 34, No. 2, pp. 400-421. doi: 10.1016/j.annals.2006.10.005.

15. Konecnik Ruzzier, M. and Ruzzier, M.: The customer's perspective on the tourism destination brand: A structural equation modeling study. Transformations in Business and Economics, 2008, Vol. 7, No. 1, pp.169-184.

16. Konecnik Ruzzier, M.: Destination branding: Theory and research. Saarbrücken: Lambert Academic Publishing, 2010, ISBN: 978-3838354590.

17. Kotler, P.: Principles of Marketing. 5th edn. New Jersey: Prentice Hall, 1991, 442 p. ISBN: 0-13-262254-8.

18. Simon, C. J. and Sullivan, M. W.: The Measurements and Determinants of Brand Equity: A Financial Approach, Working Paper, Graduate School of Business, University of Chicago, from Keller (1993).

19. Mayo, E.: Regional Images and Regional Travel Behavior. Proceedings of the Fourth Annual Travel Research Association Conference. Salt Lake City, Utah: Travel Tourism Research Association, 1973, pp. 211-217p. ISBN: 1-873150-96-2.

20. Morgan, N., Pritchard, A. and Piggot, R.: New Zealand, $100 \%$ pure. The creation of a powerful niche destination brand. Journal of Brand Management, 2002, Vol. 9, No. 4/5, pp. 335354. https://doi.org/10.1177/1356766708094755

21. Murphy P., Prichard, M. and Smith, B.: The Destination Product and its Impact on Traveller Perception. Tourism Management, 2000, Vol. 21, pp. 43-52. doi:10.1016/S02615177(99)00080-1.

22. Oppermann, M.: Tourism destination loyalty. Journal of Travel Research, 2000, Vol. 39, No. 3, pp. 78-84. https://doi.org/10.1177/004728750003900110

23. Pike, S.: Destination Image Analysis: A Review of 142 Papers from 1973 to 2000. Tourism Management,2002, Vol. 23, No. 5, pp. 541-549. ISSN: 0261-5177.

24. Pike, S. and Bianchi, C.: Destination brand equity for Australia: testing a model of CBBE in short haul and long haul markets. Journal of Hospitality and Tourism Research, 2016, Vol. 40, No. 1, pp. 114-134. doi:10.1177/1096348015619411. 25. Tasci, A.D.A., Gartner, W.C., Cavusgil, S.T.: Conceptualization and operationalization of destination image. Journal of Hospitality and Tourism Research, 2007, Vol. 31, No. 2, pp. 194-223. Doi: 10.1177/1096348006297290.

26. Yoo, B. and Donthu, N.: Developing and Validating a Multidimensional Consumer-Based Brand Equity Scale. Journal of Business Research, 2001, Vol. 52, No. 1, pp. 1-14. http://dx.doi.org/10.1016/S0148-2963(99)00098-3

Primary Paper Section: A

Secondary Paper Section: AE, AH 